\title{
PENGARUH BUDAYA ORGANIASI TERHADAP KUALITAS PELAYANAN PDAM TIRTA MASSEREMPULU DI KABUPATEN ENREKANG
}

\author{
${ }^{1}$ Sumria, ${ }^{2}$ Muhammadiah, ${ }^{3}$ Ihyani Malik \\ 1) Jurusan Ilmu Administrasi Negara Fisip Unismuh \\ 2) Jurusan Ilmu Administrasi Negara Fisip Unismuh \\ 3) Jurusan Ilmu Administrasi Negara Fisip Unismuh
}

\begin{abstract}
The objectives of this research is to find out the influence of organizational culture on the quality of service of PDAM Tirta Masserempulu, Enrekang Regency. The population is all customers in the Office of PDAM Tirta Masserempulu, Enrekang Regency. The sample used is a customer in the Office of PDAM Tirta Masserempulu, Enrekang Regency as many as 30 customers. The technique of determining the sample is by simple random sampling. The data analysis technique used was the analysis of the reliability test method and validity test, simple regression analysis of Pearson product moment (r) through the SPSS 20.00 program at a significant level of $\alpha=0.05$. The results showed that there was a significant influence between organizational culture on service quality PDAM Tirta Masserempulu, Enrekang Regency with a regression coefficient of 0.389 is positive, so it can be said that the direction of influence of variable $X$ on $Y$ is positive. While $76.9 \%$ is influenced by other factors not referred to in this study.
\end{abstract}

Key word: organizational culture and service quality

\begin{abstract}
ABSTRAK
Penelitian ini bertujuan untuk mengetahui pengaruh budaya organisasi terhadap kualitas pelayananan PDAM Tirta Masserempulu Kabupaten Enrekang. Populasinya adalah seluruh pelanggan di Kantor PDAM Tirta Masserempulu Kabupaten Enrekang. Sampel yang digunakan adalah pelanggan di Kantor PDAM Tirta Masserempulu Kabupaten Enrekang sebanyak 30 pelanggan. Teknik penentuan sampel adalah dengan cara simple random sampling. Teknik analisis data yang digunakan adalah analisis metode uji reabilitas dan uji validitas, analisi regresi sederhana Pearson product moment (r) melalui program SPSS 20.00 pada taraf signifikan $\alpha=0,05$. Hasil penelitian menunjukkan bahwa adanya pengaruh yang signifikan antara budaya organisasi terhadap kualitas pelayanan PDAM Tirta Masserempulu Kabupaten Enrekang dengan koefisien regresi sebesar 0,389 tersebut bernilai positif sehingga dapat dikatakan bahwa arah pengaruh variable $\mathrm{X}$ terhadap $\mathrm{Y}$ adalah positif. Sedangkan $76,9 \%$ dipengaruhi oleh faktor lain yang tidak termaksud dalam penelitian ini.
\end{abstract}

Kata Kunci: budaya organisasi dan kualitas pelayanan. 


\section{PENDAHULUAN}

Indonesia merupakan bangsa merdeka yang telah dikaruniai berupa kekayaan alam di bumi Negara Indonesia ini, satu satunya adalah sangat mutlak digunakan untuk umat manusia sepanjang masa, demi kebutuhan kehidupan seharihari. Mengingat fungsi dan kebutuhan sebagai kebutuhan pokok hidup manusia dan merupakan sumber alam yang terkandung dalam bumi, maka tepatlah kiranya landasan pokok tentang pemanfaat airdan kekayaan yang terkandung di wilayah Indonesia diatur dalam UUD 45 pasal 33 ayat (3) yang berbunyi: "Bumi dan air dan kekayaan alam yang terkandung didalamnya dikuasai oleh negara dan dipergunakan untuk sebesarbesarnya kemakmuran rakyat."

Berdasarkan landasan tersebut dapat kita hayati, bahwa negara kita telah mempunyai keinginan besar untuk menguasai dan mengatur pemanfaatan air demi terpenuhnya kebutuhan warga masyarakat secara adil dan merata, maka dalam hal ini penyediaan air minum memerlukan perencanaan yang matang dalam arti perlu ditangani secara efisien dan efektif sehingga dapat memberikan pelayanan yang baik bagi masyarakat. Kebutuhan yang mendasar selalu meningkat dan berkembang sejalan dengan pertumbuhan penduduk dan kemajuan diberbagai bidang. Akibat kemajuan diberbagai bidang pembangunan, karena sejalan dengan kemajuan itu semakin meningkat pula kebutuhan warga masyarakat.

Pemberiaan peraturan umum oleh aparatur pemerintah kepada masyarakat merupakan perwujudan peranan birokrasi sebagai dinamisator tugas-tugas dan juga mengarah pelayanan masyarakat dengan penuh pengabdian, memperbaiki tata laksana pelayanan masyarakat secara lebih tertib dan teratur sebab jika birokrasi tertib dan teratur maka dengan sendirinya akan mempunyai wibawa serta mendapat dukungan penuh dari masyarakat. hakikat fungsi aparatur pemerintah adalah sebagai abdi negara dan abdi masyarakat yang berkewajiban untuk memberikan pelayanan kepada masyarakat. Oleh sebab itu, untuk meningkatkan kualitas pelayanan masyarakat, maka perbaikan kinerja aparatur sangat dipentingkan. Dalam kaitan ini kebijaksanaan pemerintah untuk kualitas pelayanan 
masyarakat harus direncanakan secara transparan serta lebih mengefektifitaskan tugas dan fungsi lembaga pengawasan.

Pelayanan adalah serangkaian kegiatan yang bersifat tidak dapat dirabah yang terjadi akibat dari adanya hubungan antara konsumen dengan karyawan untuk memecahkan permasalahan konsumen pelanggan (Ratminto \& Atik Septi Winarsih, 2006). Pelayanan Menurut Moenir (2010) adalah kegiatan yang dilakukan oleh seseorang atau sekelompok orang dengan landasan faktor materi melalui sistem, prosedur dan metode tertentu dalam rangka usaha memenuhi kepentingan orang lain sesuai dengan haknya. Dengan cara demikian kualitas pelayanan diharapkan lebih meningkat. Pengertian pelayanan juga dikemukakan oleh Endar Sugiarto (2002) yaitu sesuatu yang dilakukan untuk memenuhi kebutuhan orang lain (konsumen, custumer, tamu dan sebagainya) sehingga tingkat pemuasaannya dapat dirasakan oleh masyarakat. Waluyo (2007) menyatakan pelayanan adalah respon terhadap kebutuhan manajerial yang akan terpenuhi apabila pengguna jasa memanfaatkan produk yang mereka inginkan. Kualitas pelayanan merupakan kesesuaian antara harapan, keinginan dengan kenyataan. Dan pada dasarnya pelayanan publik adalah memberikan pelayanan prima kepada masyarakat yang merupakan kewajiban aparatur pemerintah sebagai abdi kepada masyarakat (Ndraha: 2005). Priansya (2011) Pelayanan merupakan proses pemenuhan kebutuhan melalui aktivitas orang lain secara langsung dan menolong menyediakan segala apa yang di perlukan orang lain seperti tamu atau pembeli.

Tuntunan masyarakat terhadap kualitas pelayanan pemerintah akan semakin tinggi. tingkat kesadaran masyarakat terhadap hak dan kewajibannya sebagai warga negara semakin berkembang. Hal yang paling penting dilakukan adalah menanamkan pengertian bahwa aparat merupakan pelayanan masyarakat bukan sebaliknya, masyarakat melayani aparat. Maksimalnya suatu pelayanan dipengaruhi adanya kebiasaan yang terjadi di dalam suatu organisasi yang terus menerus dijalankan sehingga menjadi sebuah budaya yang tercipta didalam organisasi. Budaya organisasi sangat penting keberadaannya 
dalam suatu organisasi. Budaya organisasi menunjukkan suatu kemapanan dan kestabilan sebuah organisasi. Suatu organisasi yang memiliki budaya organisasi kuat tidak akan mengganggu kinerja organisasi sekalipun terjadi mutasi, seperti pergantian pemimpin atau mutasi jabatan. Robbins (2003: 81) mengemukakan bahwa budaya organisasi merupakan persepsi umum yang dibentuk oleh anggota organisasi menjadi sebuah sistem yang penggabungan pengertian, untuk menyusun kesepakatan di dalam melaksanakan tugas organisasi agar inovatif, antisipasi resiko, teliti terhadap setiap masalah serta agresif didalam melaksanakan tugas organisasi. Menurut Schein (Malik, 2015) budaya organisasi memiliki tiga tingkat yaitu: Artifak adalah sesuatu hal yang ada bersama untuk menentukan budaya serta mengungkapkan sebenarnya budaya itu kepada masyarakat yang memperhatikan budaya. Seperti produk, jasa dan bahkan pola tingkah laku dari anggota dalam sebuah organisasi. Nilai-nilai yang didukung adalah alasanalasan yang didukung oleh sebuah organisasi atau karyawan untuk melakukan sesuatu. Asumsi dasar adalah kepercayaan atau keyakinan yang dianggap sudah ada oleh anggota dalam suatu organisasi. Dengan cara penetapan yang tepat untuk melakukan sesuatu di sebuah organisasi lewat asumsi yang diucapkan.

Dikutip dari Tjiptono (2012) mendeskripsikan bahwa terdapat lima arti mengenai kualitas, salah satunya adalah jika kualitas dilihat tergantung pada orangorang yang menilainya, sehingga produk yang paling memuaskan adalah produk yang berkualitas paling tinggi, pengetahuan dan kemampuan yang baik.

Kabupaten Enrekang adalah mengusahan penyediaan air bersih untuk kebutuhan masyarakat. Masalah lain yang masih membayangi PDAM adalah distribusi pelayanan yang tidak merata terhadap masyarakat. terkadang PDAM Unit Anggeraja adalah masalah penetapan waktu distribusi air ke rumah warga khususnya di wilayah Sosok yang mendapatkan air di mulai pada pukul 22.00 wita. Sehingga masyarakat terkadang menunggu pembagian air PDAM ini pada malam hari. Sehingga budaya yang demikian akan berpengaruh terhadap kualitas pelayanan dan tentunya 
kinerja organisasi di mata masyarakat tidak baik atau buruk.

Pelayanan itu tidak serta merta baik dan memuaskan masyarakat, Berbagai masalah yang dihadapi oleh PDAM ini harus segera diselesaikan, disamping itu pelayanan yang baik dan adil harus selalu diberikan oleh PDAM Unit Anggeraja kepada masyarakat sebagai instansi pemerintah yang diberi amanah menyelenggarakan pelayanan publik. Berbagai isu yang timbul dikalangan masyarakat, ternyata hal pelayanan yang diterima oleh masyarakat atau perorangan khususnya pelayanan air bersih yang diberikan oleh PDAM Unit Anggeraja belum terasa belum memenuhi harapan semua pihak baik dari kalangan masyarakat umum maupun dari kalangan pemerintah sendiri. PDAM Kabupaten Enrekang yang merupakan salah satu perusahaan daerah yang mengelola pendistribusian air bersih ke masyarakat Enrekang, sering mengalami kendalakendala yang berkaitan dengan budaya organisasi, dan kinerja pelayanan karyawan. PDAM merupakan salah satu Satuan Kerja Perangkat Daerah yang dimana mempunyai tugas menyediakan air secara cukup dan memadai bagi masyarakat dalam menjalankan kehidupan sehari-hari.

Air adalah sumber alam yang sangat penting dan besar pengaruhnya kepada kehidupan kita umat manusia. PDAM bertugas untuk memenuhi hal tersebut sehingga kinerja pelayanan PDAM harus baik agar air yang akan disajikan sudah cukup memenuhi kebutuhan masyarakat. Serta adanya perilaku masyarakat yang belum mengedepankan prinsip pelayanan yang baik. Seperti karyawan menganggap posisi mereka bukan sebagai pelayan masyarakat.

\section{METODE PENELITIAN}

Penelitian ini menggunakan jenis penelitian kuantitatif, tujuannya adalah mengembangkan dan menggunakan model-model sistematis penelitian yang manfaatnya dirasakan untuk jangka panjang lamanya karena penelitian ini biasanya dilakukan untuk kebutuhan peniliti sendiri. Penelitian murni juga mencakup penelitian-penelitian yang dilakukan dalam kerangka akademis. Teknik sampel yang digunakan pada peneliti ini teknik non ptobability 
sampling yang digunakan adalah sampling kuota, yaitu teknik untuk menentukan sampel dari populasi PDAM Tirta Masserempulu Enrekang yang mempunyai ciri-ciri tertentu sampai jumlah (kuota) yang diinginkan. Berdasarkan penjelasan tersebut. Maka jumlah sampel yang diambil dari penelitian ini sebanyak 30 orang dari 86 populasi yang ada. Adapun metode metode analisis sebagai berikut: (1) Uji Normalitas, (2) Uji Reabilitas dan Validitas, (3) Uji Regresi Sederhana. Analisis yang digunakan dalam penlitian ini merupakan bagian yang penting, sebab melalui analisa data ini akan tampak manfaatnya terutama dalam pemecahan masalah penelitian dan mencapai tujuan akhir penelitian. Setelah data yang di perlukan data tersebut diolah.

\section{HASIL DAN PEMBAHASAN}

PDAM sebagai perusahaan milik daerah adalah salah satu alat kelengkapan otonomi daerah yang bergerak di bidang pengelolaan air minum. Perusahaan daerah ini diselenggarakan atas azas ekonomi perusahaan dalam kesatuan sistema pembinaan otonomi Indonesia berdasarkan pancasila yang menjamin kelangsungan demokrasi ekonomi yang berfungsi sebagai alat untuk meningkatkan kesejateran masyarakat. PDAM Tirta Masserempulu Kabupaten Enrekang didirikan berdasarkan peraturan daerah kabupaten Enrekang Nomor; 13 Tahun 1986, tanggal 8 Desember 1986, dan dimuat dalam lembaran Daerah Kabupaten Enrekang Nomor 7 Tahun 1987, Seri D Nomor: 4. Perusahaan mulai beroprasi sejak diserataterimakan Badan Pengelolaan Air Minum (BPAM) kepada bupati Enrekang sesuai dengan berita acara Nomor 690/Ekon per 690/1067 tanggal 16 Desember 1992.

Berikut ini akan di kemukakan gambaran umum respondek yang menjadi obyek penelitian ini. Responden dalam penelitian ini adalah masyarakat ysng sudah melakukan kunjungan ke PDAM Tirta Massenrempulu Kabupaten Enrekang minimal 3 kali kunjungan. Kuesioner yang disebar sebanyak 30 kuesioner yang di berikan kepada responden. Responden di bagi menjadi 5 kategori. Jenis kelamin dapat menunjukkan kondisi fisik dari seseorang. Gambaran umum mengenai pengunjung PDAM Tirta Massenrempulu Kabupaten Enrekang berdasarkan jenis 
kelamin dapat di tabulasikan sebagai berikut: analisis deskriptif data pengaruh antara budaya organisasi terhadap kualitas

\begin{tabular}{|c|c|c|}
\hline Jenis Kelamin & N & Persentase (\%) \\
\hline Laki - laki & 19 & 63,70 \\
\hline Perempuan & 11 & 36,30 \\
\hline Total & $\mathbf{3 0}$ & $\mathbf{1 0 0 \%}$ \\
\hline
\end{tabular}

Dari tabel ini menunjukkan bahwa karakteristik pengunjung PDAM Tirta Masserempulu Kabupaten Enrekang berdasarkan jenis kelamin diperoleh data terbanyak pada pada kelompok jenis kelamin laki-laki dengan jumlah 19pengunjung $(63,70 \%)$ dan terendah pada kelompok jenis kelamin perempuan dengan jumlah 11 pengunjung $(36,0 \%)$. Analisis deskriptif data dari hasil penelitian bertujuan untuk memberikan gambaran secara umum mengenai penyebaran distribusi data pengaruh budaya organisasiterhadap kualitas pelayanan PDAM Tirta Masserempulu Kabupaten Enrekang, baik berupaukuran letak distribusi frekuensi. Nilai-nilai yang disajikan setelah diolah dari data mentah dengan menggunakan statistik deskriptif, yaitu nilai rata-rata, standar deviasi (simpangan baku), rentang, minimal, maksimal serta jumlah total. Hasil pelayanan PDAM Tirta Masserempulu Kabupaten Enrekang, dapat dikemukakan sebagai berikut: Berdasarkan data hasil penelitian, kualitas pelayanan $\operatorname{PDAM}(\mathrm{Y})$, dari 30sampel diperoleh nilai rata-rata sebesar 67.4000, nilai simpangan baku sebesar 4.80373, nilai varians sebesar 23.076 dan diperoleh nilai rentang sebesar 20.00 dari selisih antara nilai minimal 57.00 dan nilai maksimal 77.00 serta jumlah total sebesar 2022.00. Berdasarkan data hasil penelitian pada tabel 4.5 di atas, pengaruh budaya organisasi(X), dari 30sampel diperoleh nilai rata-rata sebesar 82.6667, nilai simpangan baku sebesar 5.93257, nilai varians sebesar 35.195 dan diperoleh nilai rentang sebesar 25.00 dari selisih antara nilai minimal 67.00 dan nilai maksimal 92.00 serta diperoleh nilai jumlah total sebesar 2480.00. Di lihat dari factor usia, responden di kelompokkan kedalam 5 kategori, menunjukkan bahwa 
kelompok usia pengunjung PDAM Tirta Masserempulu Kabupaten Enrekang yang paling dominan Responden Usia, peneliti membagi adalah kelompok umur 21-30 tahun yakni sebesar 17 pengunjung $(57,10 \%)$, kemudian diiukuti umur 31-40 tahun sebesar 6 pengunjung (19,80\%), umur $<20$ tahun yakni sebesar 4 pengunjung $(13,20 \%)$, umur 41-50 tahun yakni 2 pengunjung $(6,60 \%)$. Sedangkan kelompok terkecil yaitu pada usia > 50 tahun yakni 1 pengunjung $(3,30 \%)$. Tingkat pendidikan mencerminkan tingkat intelektualitas dari seseorang. Gambaran umum mengenai pengunjung pengguna jasa PDAM Tirta Masserempulu Kabupaten Enrekang berdasarkan kelompok pendidikan. Jumlah pengunjung terbanyak adalah dari kalangan yang berpendidikan SLTA atau sederajat sebanyak 12 pengunjung (40,60\%), SLTP atau sederajat sebanyak 8 pengunjung $(26,40 \%)$, Sarjana (S1) dan SD atau sederajat yang masing-masing sebanyak 4 pengunjung (13,20\%). Dan kalangan terkecil yaitu tingkat pendidikan Diploma (D1-D3) sebanyak 2 pengunjung $(6,60 \%)$.

Pekerjaan mecerminkan status sosial. Gambaran umum mengenai pengunjung PDAM Tirta Masserempulu Kabupaten Enrekang berdasarkan kelompok pekerjaan dapat di tabulasikan jumlah pengunjung terbanyak adalah dari jenis pekerjaan lainnya sebanyak 12 pengunjung (40,60\%), Pengunjung Negeri sebanyak 9 pengunjung (29,70\%), Wiraswasta sebanyak 4 pengunjung (13,20\%), Pengunjung Swasta sebanyak 3 pengunjung $(9,90 \%)$. Dan jenis pekerjaan Pelajar paling kecil yaitu sebesar 2 pengunjung $(6,60 \%)$. Berdasarkan diatas yang merupakan rangkuman hasil pengujian normalitas data pada tiap-tiap penelitian, dapat diuraikan sebagai berikut : Dalam pengujian normalitas data kualitas pelayanan PDAM Tirta Masserempulu Kabupaten Enrekang, dari30 sampel diperoleh nilai $\mathrm{KS}-\mathrm{Z}=0,547$ dengan tingkat probabilitas $=0,926$ serta lebih besar dari pada nilai $\alpha 0,05$ atau pada taraf signifikan 95\%. Dengan demikian data kualitas pelayanan PDAM Tirta Masserempulu Kabupaten Enrekang yang diperoleh berdistribusi normal; Dalam pengujian normalitas pengaruh budaya organisasi, dari 30 sampeldiperoleh nilai $\mathrm{KS}-\mathrm{Z}=0,496$ dengan tingkat probabilitas $=$ 0,967 serta lebih besar dari pada nilai $\alpha$ 
0,05 atau pada taraf signifikan 95\%. Dengan demikian data pengaruh budaya organisasiyang diperoleh berdistribusi normal.

Analisis deskriptif data dari hasil penelitian bertujuan untuk memberikan gambaran secara umum mengenai penyebaran distribusi data pengaruh budaya organisasiterhadap kualitas pelayanan PDAM Tirta Masserempulu Kabupaten Enrekang, baik berupaukuran letak distribusi frekuensi. Nilai - nilai yang disajikan setelah diolah dari data mentah dengan menggunakan statistik deskriptif, yaitu nilai rata - rata, standar deviasi (simpangan baku), rentang, minimal, maksimal serta jumlah total. Hasil analisis deskriptif data pengaruh antara budaya organisasi terhadap kualitas pelayanan PDAM Tirta Masserempulu Kabupaten Enrekang, dapat dikemukakan sebagai berikut : Berdasarkan data hasil penelitian pada tabel 4.5 diatas, kualitas pelayanan $\operatorname{PDAM}(\mathrm{Y})$, dari 30sampel diperoleh nilai rata-rata sebesar 67.4000, nilai simpangan baku sebesar 4.80373, nilai varians sebesar 23.076 dan diperoleh nilai rentang sebesar 20.00 dari selisih antara nilai minimal 57.00 dan nilai maksimal 77.00 serta jumlah total sebesar 2022.00 .

Berdasarkan data hasil penelitian pada tabel 4.5 di atas, pengaruh budaya organisasi(X), dari 30sampel diperoleh nilai rata-rata sebesar 82.6667, nilai simpangan baku sebesar 5.93257, nilai varians sebesar 35.195 dan diperoleh nilai rentang sebesar 25.00 dari selisih antara nilai minimal 67.00 dan nilai maksimal 92.00 serta diperoleh nilai jumlah total sebesar 2480.00. Suatu data penelitian yang akan dianalisis secara statistik harus memenuhi syarat-syarat analisis dengan uji statistik regresi, maka perlu dilakukan uji persyaratan analisis pengaruh antara budaya organisasi terhadap kualitas pelayanan PDAM Tirta Masserempulu Kabupaten Enrekang pada penelitian ini terkumpul, maka sebelum dilakukan analisis statistik untuk pengujian hipotesis, terlebih dahulu dilakukan uji persyaratan yaitu normalitas dengan uji KolmogorovSmirnov Z. 


\begin{tabular}{|l|l|l|l|}
\hline Variabel & $t_{- \text {hitung }}$ & Sig. & $t_{-\operatorname{tabel}(\alpha=0,05)}$ \\
\hline $\begin{array}{l}\text { Hubungan antara pengaruh } \\
\text { budaya organisasi(X) }\end{array}$ & & & \\
dengankualitas pelayanan & & 0,000 & 2,048 \\
PDAM (Y) & & & \\
\hline
\end{tabular}

Koefisin regresi yang diperoleh pengaruh antara budaya organisasiterhadap kualitas pelayanan PDAM Tirta Masserempulu Kabupaten Enrekang sebesar 0,480 termasuk dalam interpretasi koefisien regresi pada kategori sedang. Nilai ini berada pada kelas interval antara 0,30 0,599. Hal ini menunjukan hubungan yang kuatantara pengaruh budaya organisasi terhadap kualitas pelayanan PDAM Tirta Masserempulu Kabupaten Enrekang. Sedangkan tingkat signifikan koefesien regresi satu sisi (1-tailed) dari output diukur dari probabilitas menghasilkan nilai signifikansi 0,000. Karena probabilitas dibawah $\alpha 0,05$, maka pengaruh budaya organisasimemiliki hubungan langsung yang positifdengan kualitas pelayanan PDAMsignifikan. Pengaruh tersebut berlaku untuk sampel 30 pengunjung PDAM Tirta Masserempulu Kabupaten Enrekang dan belum berlaku pada populasi yang berjumlah 86pengunjung, maka perlu diuji signifikansinya. Selanjutnya untuk mengetahui signifikansi regresiproduct momentdapat dilihat pada. Berdasarkan analisis koefisien regresi uji-t pada tabel 4.5diatas diperoleh nilait_hitung sebesar 2,898 dan t_tabel (30-2 (28); 0,05) sebesar 2,048. Berdasarkan hasil tersebut, maka dapat disimpulkan bahwa koefisien regresi (uji-t) antara pengaruh budaya organisasiterhadap kualitas pelayanan PDAM Tirta Masserempulu Kabupaten Enrekang signifikan atau $\mathrm{H}_{0}$ ditolak dan diterima $\mathrm{H}_{1}$. Dengan demikian dapat disimpulkan bahwa hipotesis ada hubungan antara pengaruh budaya organisasiterhadap kualitas pelayanan PDAM Tirta Masserempulu Kabupaten Enrekang diterima. 
Analisis regresi dilakukan untuk mengetahui pengaruhvariabel bebas dengan variabel terikat. Analisis regresi yang digunakan adalah analisis regresiproduct moment (r) pada taraf signifikan $95 \%$ atau $\alpha 0,05$ selanjutnya untuk menguji signifikansi antara variabel (X) dengan variabel (Y) yang berlaku pada populasi maka dilanjutkan dengan menguji signifikansi regresiproduct moment dan selanjutnya diuji menggunakan regresi ganda atau dengan menghitung koefisien diterminasi (R_square) pada output SPSS. Hal tersebut dimaksudkan untuk mengetahui pengaruhbudaya organisasiterhadap kualitas pelayanan PDAM Tirta Masserempulu Kabupaten Enrekang. Hipotesis yang diuji dalam penelitian ini adalah"terdapat pengaruhyang positif antara budaya organisasiterhadap kualitas pelayanan PDAM Tirta Masserempulu Kabupaten Enrekang".Nilai-nilai yang dibutuhkan dalam melihat memiliki pengaruh positif antara budaya organisasi(X) dengan kualitas pelayanan PDAM (Y).

Berdasarkan analisis koefisien regresi antara variabel bebas terhadap variabel terikat dalam pengujian hipotesis perlu dikaji lebih lanjut dengan memberikan interpretasi keterkaitan antara hasil analisis yang dicapai dengan teoriteori yang mendasari penelitian ini. Penjelasan ini diperlukan agar dapat diketahui kesesuaian teori-teori yang dikemukakan dengan hasil penelitian yang diperoleh. Adapun penjelasan untuk memberikan kejelasan keterkaitan variabel bebas terhadap variabel terikat adalah "Pengaruh Budaya Organisasi Terhadap Kualitas Pelayanan PDAM Tirta Masserempulu Kabupaten Enrekang”. Dari hasil pengujian hipotesis dapat dikemukakan bahwa terdapat pengaruh antara budaya organisasiterhadap kualitas pelayanan PDAM Tirta Masserempulu Kabupaten Enrekang. Hal ini dapat diketahui dari hasil analisis diperoleh nilai regresi (r) 0,480 dengan tingkat probabilitas $0,000<\alpha 0,05$ yang dijelaskan melalui koefisien regresi sederhana (R) diperoleh nilai sebesar 0,480 dan r_tabel (30;0,05) sebesar 0,361 sedangkan r_tabel $(30 ; 0,01)$ sebesar 0,463 atau (r_hitung > r_tabel). Berdasarkan hasil tersebut, maka dapat disimpulkan bahwa terdapat pengaruh budaya organisasiterhadap kualitas pelayanan 
PDAM Tirta Masserempulu Kabupaten Enrekang diterima, atau terima $\mathrm{H} 1$ dan tolak H0. Selanjutnya pada analisis koefisin determinasi (Rsquare) atau regresi ganda (R2) hasil pengkuadratan r_hitungsebesar $\quad 0,480$ diperoleh nilai sebesar 0,231 yang berarti $53,3 \%$ dari variabel kualitas pelayanan PDAM (Y) disebabkan oleh pengaruh budaya organisasi (X). Hal ini berarti 23,1\%data pengaruh budaya organisasi (X) memberikanhubungan langsung terhadap kualitas pelayanan PDAM (Y) dan sisanya sebesar $76,9 \%$ atau $(100 \%-23,1 \%=$ $76,9 \%)$ disebabkan oleh faktor-faktor lain yang tidak temasuk dalam penelitian ini.Hasil ini menunjukkan makna bahwa pengaruh budaya organisasimerupakan komponen psikologi yang penting agar kualitas pelayanan PDAM Tirta Masserempulu Kabupaten Enrekang dapat dilakukan dengan baik dan benar. Pengaruh budaya organisasi menjadi faktor penentu diberbagai cabang kualitas pelayanan dan sebagainya. Menghubungkan teori diatas dengan hasil penelitian ini maka sangat jelas bahwa terdapat pengaruh budaya organisasi dengan kualitas pelayanan PDAM Tirta
Masserempulu Kabupaten Enrekang. Oleh karena itu, untuk meningkatkan kualitas pelayanan tidak hanya dilihat dari modernnya fasilitas yang ada, tetapi memperhatikan faktor lain dan khususnya berfokus pada pengunjung agar pengunjung merasakan kepuasan sehingga tercipta loyalitas terhadap PDAM Tirta Masserempulu Kabupaten Enrekang tersebut.

Kualitas pelayanan disuatu organisasi publik berkaitan erat dengan Budaya organisasi. Hal yang melatarbelakangi adalah motif dari adanya instansi pemerintah, yakni mengadakan pelayanan publik sehingga kondisi didalam instansi pemerintah yang bisa mempengaruhi kualitas pelayanan salah satunya adalah budaya organisasi. Semakin kuat budaya organisasi semakin besar dorongan para karyawan untuk mengoptimalkan pelayanan kepada semua pelanggannya. Budaya organisasi merupakan perekat organisasi yang mengikat anggota organisasi melalui nilainilai yang ditaati bersama. Budaya organisasi tercermin dalam perilaku keseharian anggotanya, berarti pula merupakan praktek sehari-hari di tempat 
kerja. Kualitas pelayanan akan membaik seiring dengan internalisasi budaya organisasi. Ini berarti semakin kuat budaya organisasi atau nilai-nilai dasar yang telah disepakati, maka semakin baik kualitas pelayanan yang dihasilkan di PDAM Tirta Masserempulu Kabupaten Enrekang.

Pengaruh budaya organisasi merupakan kekuatan kepercayaan atau keyakinan yang dapat dikembangkannya sendiri atau dikembangkan oleh sejumlah kekuatan luar yang pada intinya berkisar sekitar imbalan moneter dan imbalan nonmoneter, yang dapat mempengaruhi hasil kerjanya secara positif atau secara negatif, hal mana tergantung pada situasi dan kondisi yang dihadapi orang bersangkutan. Besar pengaruh dari budaya organisasi terhadap kualitas pelayaan PDAM Tirta Masserempulu Kabupaten Enrekang pada dasarnya bahwa pengaruh budaya organisasi merupakan kondisi yang dapat mendorong seseorang untuk melakukan pelayanan yang baik dan maksimal. Dalam hal ini melakukan kualitas pelayanan, pengaruh budaya organisasi dapat dikatakan sebagai keseluruhan daya penggerak terhadap orang/pengunjung yang menimbulkan, menjamin kelangsungan dan memberikan arah kegiatan pelayanan, sehingga diharapkan tujuan dapat tercapai. Bagi pengunjung yang selalu memerhatikan program pelayanan yang diberikan, bukanlah masalah bagi atasan.Pengunjungyang demikian biasanya dengan kesadaran sendiri memerhatikan penjelasan atasan. Di sini tugas atasan adalah membangkitkan pengaruh budaya organisasi pengunjung sehingga ia mau bekerja dalam hal ini dalam melakukan kualitas pelayanan yang memuaskan. Untuk mendapatkan hasil yang lebih baik, atasanakan memerlukan strategi-strategi yang lebih baik untuk mepengaruhi budaya organisasi pengunjung agar dapat mewujudkan kualitas yang lebih tinggi di dalam aktivitas pelayanan dalam hal ini dalam melakukan pelayanan PDAM Tirta Masserempulu Kabupaten Enrekang. Kualitas pelayanan PDAM Tirta Masserempulu Kabupaten Enrekang merupakan salah satu indikator dari keberhasilan pengaruh budaya organisasi karena kualitas pelayanan tidak dapat di tentukan oleh pihak yang melayani saja, tetapi lebih dominan ditentukan oleh pihak yang dilayani sebab kualitas pelayanan 
dapat diukur berdasarkan harapan-harapan dalam memenuhi kepuasannya. Hasil ini menunjukkan bahwa untuk meningkatkan pengaruh budaya organisasi terhadap kualitas pelayanan PDAM Tirta Masserempulu Kabupaten Enrekang, maka harus memiliki indikator peningkatan pengaruh budaya organisasiyang mendukung terjadinya kontraksi secara maksimal dalam menghasilkan.Kualitas pelayanan PDAM Tirta Masserempulu Kabupaten Enrekang.Apa yang telah dihasilkan dalam penelitian ini, yang memperlihatkan adanya hubungan antara pengaruh budaya organisasi terhadap kualitas pelayanan PDAM Tirta Masserempulu Kabupaten Enrekang.

\section{KESIMPULAN}

Berdasarkan hasil analisis data dan uraian pembahasan yang telah dikemukakan maka dapat disimpulkan "ada hubungan langsung yang signifikan antara pengaruh budaya organisasi terhadap kualitas pelayanan PDAM Tirta Masserempulu Kabupaten Enrekang dengan koefisien korelasi sebesar 0,480 dalam kategori sedang. Kepada orang/pengungjung agar selalu memperhatikan dan membekali diri mengenai tugas dan kepuasan pelayanan tentang bagaimana pentingnya mengembangkan pelayanan seperti pengaruh budaya organisasi untuk lebih meningkatkan kualitas pelayanan pada PDAM Tirta Massenrempulu Enrekang. Kepada atasan, maupun pemerhati pada PDAM, direkomendasikan bahwa kiranya dalam upaya meningkatkan kualitas pelayanan pada pengungjung dan coutumer, hendaknya perlu memperhatikan unsur-unsur pengaruh budaya organisasi.

\section{DAFTAR PUSTAKA}

Endar Sugiarto. 2002. Psikologi Pelayanan dalam Industri Jasa.

Jakarta: Gramedia Pustaka Utama. Talidizuhu Ndraha.2005.Teori Budaya Organisasi. Jakarta: Rineka Cipta

Malik, Ihyani. 2015. Budaya Organisasi Pemerintahan. Yogyakarta: Leutikabooks.

Moenir, H.A.S. 2010. Manajemen Pelayanan Umum di Indonesia.

Bumi Aksara. Jakarta

Ratminto, dan Atik Septi Winarsih. 2006. Manajemen Pelayanan. Pustaka Pelajar. Yogyakarta.

Republik Indonesia, Undang- Undang Dasar Tahun 1945, tentang kekayaan alam yang terkandung didalamnya dikuasai oleh negara 
Robbins, Stephen P. 2003. Perilaku Organisasi Jilid 1. Edisi 9. Penerjemah Tim Indeks. Jakarta : PT. Indeks, Gramedia Grup.

Suanto, Priansa,2011. Manajemen SDM dalam organisasi public dan bisnis, bandung: alfabeta

Tjiptono, fandy. (2012). Service management: Mewujudkan layanan Prima. Yogyakarta: CV.

Andi Offset

Waluyo, 2007, Manajemen Publik : Konsep, Aplikasi dan Impelementasi Dalam Pelaksanaan Otonomi Daerah 